\title{
Sammenhæeng mellem ny teknologi i seniorarbejdslivet og beslutningen om at forlade arbejdsmarkedet før eller efter folkepensionsalderen
}

\author{
Emil Sundstrup, Jeppe Ajslev \& Lars Louis Andersen
}

Den demografiske udvikling med en aldrende befolkning og den lovbestemte hævelse af pensionsalderen har medvirket til, at især spørgsmålet om seniorers deltagelse på arbejdsmarkedet fylder meget i den offentlige debat. Sideløbende gennemgår arbejdsmarkedet, og den måde vi arbejder på, grundlæggende forandringer i disse år, hvor en stigende grad af automatisering og digitalisering i vid udstrækning - og på tværs af brancher - forandrer arbejdets indhold og organisering. Artiklen, der tager udgangspunkt i Arbejdslivsundersøgelsen (survey blandt 10.776 seniormedarbejdere) i projektet SeniorArbejdsLiv, undersøger hvorvidt indførsel af- og uddannelse i ny teknologi har betydning for seniorernes beslutning om at forlade arbejdsmarkedet før eller efter folkepensionsalderen på tværs af tre distinkte jobfunktionskategorier (arbejde med symboler, arbejde med mennesker, arbejde med produktion).

Nøgleord: teknologi, automatisering, digitalisering, seniorer, arbejdsmiljø, arbejdsliv

\section{Baggrund}

Den demografiske udvikling med en aldrende befolkning og den lovbestemte hævelse af pensionsalderen har medvirket til, at især spørgsmålet om seniorers deltagelse på arbejdsmarkedet fylder meget i den offentlige debat. Sideløbende med den demografiske udvikling gennemgår arbejdsmarkedet, og den måde vi arbejdet på, grundlæggende forandringer i disse år. Dette gælder bl.a. en stigende grad af automatisering og digitalisering, hvor implementering af nye teknologier i vid udstrækning - og på tværs af brancher - forandrer arbejdets indhold og ofte også arbejdets organisering. I et fastholdelsesper- spektiv, kan det betyde, at den arbejdende befolkning, herunder også seniormedarbejderne, skal udvise endnu højere grad af tilpasningsdygtighed for at kunne varetage fremtidens arbejdsliv og dets udfordringer. Dette syntes især udfordrende i lyset af, at seniormedarbejdere vurderes mere negativt end yngre arbejdstagere i forhold til at beherske ny teknologi og viljen til at lære nyt (McGregor \& Gray, 2002; Meng et al., 2019).

Seniorerne er en meget differentieret gruppe af lønmodtagere, med forskelligartet uddannelsesbaggrund og helbred, som udfører mange forskellige typer arbejde med meget forskellige arbejdsmiljøpåvirkninger (Bach 
et al., 2018; Bach \& Johnsen, 2016). De teknologiske løsninger i arbejdet, og hvordan de reelt påvirker seniorernes syn på at blive eller gå, er derfor i høj grad afhængig af, hvilket arbejde seniorerne udfører. For at få bedre greb om indførelse og uddannelse i ny teknologi som push- og stay-faktorer (faktorer der medvirker til at seniorerne hhv. puffes ud af arbejdsmarkedet før- eller trækker sig tilbage senere end pensionsalderen), samt for hvem det spiller en rolle, er det vigtigt at komme tættere på seniorernes konkrete arbejdsfunktioner. For eksempel kan indførelse af teknologi inden for arbejde med produktion reducere de fysiske belastninger i arbejdet (Arvidsson et al., 2012), og derved bidrage til at reducere risikoen for førtidig afgang fra arbejdsmarkedet ( Andersen et al., 2016; Sundstrup et al., 2017) og samtidig potentielt skabe mere motiverende arbejdsopgaver, hvor planlægning og styring af maskiner og robotter bliver kernekompetencer (Ajslev et al., 2019; Hinrichsen, 2010). På den anden side, kan teknologien også betyde, at mange af de manuelle job, der findes i arbejdet med produktion, bliver overflødiggjort, hvorved især de mindst tilpasningsdygtige seniorer kan blive skubbet ud af arbejdsmarkedet (Stacey et al., 2017), hvis de ikke forberedes tilstrækkeligt på den teknologiske udvikling (Arntz et al., 2016; Damm, 2017; Tænketanken - Den nye 3. alder, 2018). Selvom implementering af ny teknologi inden for arbejde med mennesker (f.eks. pleje af patienter eller borgere) også har potentiale til at reducere de fysiske belastninger i arbejdet, kan det tænkes at have andre indvirkninger på push og stay end indførelse af teknologi i produktionsarbejdet. Tidligere studier har vist, at velfærdsteknologi i ældreplejen kan opleves at være i konflikt med arbejdstagernes faglige identitet og værdier (Ajslev et al., 2017, 2019), hvilket potentielt kan forringe kvaliteten i arbejdet. Også inden for arbejde med symboler (vidensarbejde, kontor og IT) har ny teknologi - herunder computerteknologi og kunstig intelligens - ændret måden at arbejde med viden på. Kunstig intelligens vil i stigende grad løse stadig flere af de mere dataog informationstunge arbejdsopgaver inden for arbejde med symboler, hvilket kan ændre arbejdets indhold og organisering. Dette kan betyde mere tid til komplicerede arbejdsopgaver, en acceleration af arbejdstempoet og stigende jobusikkerhed iblandt de mindst tilpasningsdygtige. Ny teknologi kan derfor have forskellig betydning for push og stay afhængigt af, hvilke arbejde seniorerne udfører. For at undersøge dette, har undersøgelsen SeniorArbejdsLiv rekrutteret medarbejdere på tværs af brancher, som herigennem også omfatter de tre distinkte jobfunktionskategorier: arbejde med produktion, arbejde med mennesker, og arbejde med symboler (Andersen \& Sundstrup, 2019).

Foruden den måde nye teknologier påvirker seniorernes arbejde på, så har måden hvorpå de indføres også stor betydning for, hvordan teknologier relaterer sig til faglige identiteter og måder at arbejde på. Derved får implementeringsprocesser også betydning for, om den nye teknologi opleves betydningsfuld for at forlade arbejdsmarkedet før eller efter folkepensionsalderen. Hvis seniorerne inddrages i måden hvorpå ny teknologi indføres, synes det sandsynligt at teknologien i højere grad kan bidrage til at løfte fremfor forringe kvaliteten i arbejdet. Det synes ligeledes vigtigt, at seniorerne uddannes tilstrækkeligt i brugen af den nye teknologi - især hvis den nye teknologi kræver nye eller opdaterede færdigheder. Uddannelse er ligeledes blevet kædet sammen med sandsynligheden for at blive på eller forlade arbejdsmarkedet i flere videnskabelige studier (Lawless et al., 2015; Laaksonen et al., 2018; Møberg, 2011). Især ser efteruddannelse og opkvalificering ud til at være vigtige instrumenter til både at øge seniormedarbejdernes ressourcer, så de bliver bedre i stand til at håndtere de arbejdskrav 
der stilles, og bevare motivation for fortsat arbejdsmarkedstilknytning. Efteruddannelse og opkvalificering kan også medvirke til en mere fleksibel seniorarbejdskraft der er bedre rustet til at varetage skiftende jobkrav og ændringer i arbejdslivet (Møberg, 2011), hvilket især syntes relevant i forhold til den stigende grad af teknologiske løsninger i arbejdslivet. Hvorvidt inddragelse i indførslen af teknologi og tilstrækkelig uddannelse i dets brug har betydning for push og stay blandt seniormedarbejdere er dog ikke tidligere belyst.

Formålet med studiet er at undersøge, hvorvidt indførsel af ny teknologi - og uddannelse heri - har betydning for seniorernes beslutning om at forlade arbejdsmarkedet før eller efter folkepensionsalderen på tværs af tre distinkte jobfunktionskategorier (arbejde med produktion, arbejde med mennesker, og arbejde med symboler).

\section{Metode}

\section{Studiepopulation og datagrundlag}

Undersøgelsen tager udgangspunkt i medarbejderundersøgelsen i projektet SeniorArbejdsLiv, der er registreret som et kohorte-studie i ClinicalTrials.gov (identifikationsnummer: NCT03634410). Dataindsamlingen for baseline fandt sted mellem juli og oktober 2018, hvor respondenterne svarede på spørgsmål om bl.a. ny teknologi i arbejdslivet, forventet arbejdslivslængde, og efteruddannelse og opkvalificering ( Andersen \& Sundstrup, 2019). Danmarks Statistik udtrak en stikprøve på 30.000 danskere $\geq 50$ år (18.000 beskæftigede, 7000 arbejdsløse, 3000 på efterløn, 2000 på førtidspension), og potentielle deltagere modtog herefter en invitation og et personligt spørgeskema-link i e-Boks. Til analyserne i nærværende artikel inkluderede vi kun aktuelt beskæftigede lønmodtagere.
Beskæftigede lønmodtagere blev defineret ud fra tre kriterier. For det første skulle personen have været i lønnet beskæftigelse mindst 20 timer om ugen ( 86,6 / 160,3 timer om måneden) i mindst halvdelen af månederne i løbet af det seneste år fra marts 2018. For det andet skulle personen mindst have være ansat 20 timer om ugen i løbet af marts 2018. Som det sidste kriterie, måtte personen ikke have modtaget ydelser fra fleksjob, skånejob, sygedagpenge, eller barselsdagpenge. Desuden blev stikprøven stratificeret for branchegruppe med et 50/50 kompromis mellem antallet af ansatte $\mathrm{i}$ hver branche $\mathrm{i}$ Danmark og lige andel i hvert stratum. Denne udvælgelsesproces sikrede, at stikprøven var universal repræsentativ indenfor hvert stratum ( Andersen \& Sundstrup, 2019).

Blandt de inviterede beskæftigede svarede $56 \%$ på alle spørgsmålene i spørgeskemaet (dvs. de, der også svarede på andre spørgsmål om f.eks. arbejdsmiljø og helbred, som ikke er inkluderet i denne artikel). Deltagerne, der kun delvist besvarede spørgsmålene i spørgeskemaet (dvs. de spørgsmål der benyttes til nærværende artikel, og beskrives nedenfor), blev også inkluderet i analyserne. Yderligere, inkluderede vi kun dem, der i spørgeskemaet havde angivet jobfunktionskategori (arbejde med symboler, arbejde med mennesker, arbejde med produktion). Til denne inddeling blev følgende spørgsmål benyttet: "Hvad arbejder du først og fremmest med i dit daglige arbejde?" med følgende tre svarkategorier: 1) Kontorarbejde, administration, analyse, IT, 2) Arbejde med mennesker, service, omsorg, 3) Arbejde med at bearbejde, producere eller flytte ting. Til de videre analyser blev respondenterne stratificeret i forhold til disse svarkategorier: svarkategori 1 blev betegnet som arbejde med symboler, svarkategori 2 blev betegnet som arbejde med mennesker, og svarkategori 3 blev betegnet som arbejde med produktion. Således blev 10.776 beskæftigede inkluderet i analyserne svarende til $60 \%$ af den oprin- 
delige stikprøve af beskæftigede på 18.000 (5395 der arbejder med symboler; 3528 der arbejder med mennesker; 1853 der arbejder med produktion). En karakteristik af studiepopulationen er præsenteret i tabel 1.

\section{Afhoengige variable}

Seniorernes oplevelse af om ny teknologi i arbejdet kan få dem til at gå eller blive i arbejde blev vurderet ud fra følgende to spørgsmål: 1) "Den nye teknologi kan have betydning for at jeg forlader arbejdsmarkedet for min folkepensionsalder" og 2) "Den nye teknologi kan have betydning for at jeg bliver på arbejdsmarkedet til efter min folkepensionsalder". Følgende svarkategorier var knyttet til begge spørgsmål: "Ja", "Nej" og "Ved ikke". Spørgsmålene blev kun stillet til de respondenter, der angav, at de havde fået indført ny teknologi i arbejdet indenfor de seneste to år (se nedenfor).

\section{Uafhcengige variable}

Følgende spørgsmål indledte spørgeskema-sektionen omkring ny teknologi i arbejdet: "Er der indført ny teknologi i dit arbejde indenfor de seneste 2 år?" med følgende svarkategorier: "Ja", "Nej".

Dem der svarede "Ja" til ovenstående spørgsmål, modtog nedenstående spørgsmål, med følgende indledning - "Er du enig i følgende udsagn?": 1) "Jeg er blevet inddraget i den måde den nye teknologi er blevet indført", 2) "Jeg har behov for nye kompetencer som følge af den nye teknologi", 3) "Jeg tilbydes tilstroekkelig uddannelse i brug af den nye teknologi", 4) "Den nye teknologi forringer kvaliteten i mit arbejde", 5) "Den nye teknologi løfter kvaliteten $i$ mit arbejde". Følgende svarkategorier var knyttet til hvert spørgsmål: "Ja", "Nej" og "Ved ikke". I de videre analyser indgik kun respondenter, der enten svarede "Ja" eller "Nej", og i de statistiske analyser blev respondenter, der angav "Nej" til det enkelte spørgsmål, benyttet som referencegruppe (se statistikafsnittet nedenfor).

Følgende kontrolvariable indgik $i$ analyserne: alder (år) og køn (mand, kvinde).

\section{Statistik}

Logistisk regression blev benyttet til at bestemme odds ratioen for enten af forlade arbejdsmarkedet før eller efter pensionsalderen grundet ny teknologi som funktion af 1) strata (jobfunktionskategori: arbejde med symboler, arbejde med mennesker, arbejde med produktion) og 2) de uafhængige variable indenfor hvert stratum. Funktionen 'Proc Surveylogistic' i SAS-version 9.4 blev benyttet til regressionsanalyserne. Analyserne er vægtet, så de er repræsentative. Odds ratio (OR) og 95\% konfidensintervaller (95\% KI) blev beregnet for hver analyse. Til at bestemme størrelserne på OR, benyttes inddelingen af Chen et al., (Chen et al., 2010) der tidligere har sammenlignet odds ratioer med effektstørrelser (Cohen's d) og fundet, at odds ratioer på 1.68, 3.47 og 6.71 svarer til hhv. lille, medium og stor effektstørrelse. Da vi i nærværende analyse ser på sammenhænge og ikke effektstørrelser, har vi valgt at benytte svag, moderat og stærk positiv sammenhæng for odds ratioer på hhv. 1.68, 3.47 og 6.71 . For odds ratioer $<1$, benyttes den reciprokke værdi af ovenstående ratioer, således at odds ratioer på $0.60,0.29$ og 0.15 svarer til hhv. svag, moderat og stærk negativ sammenhæng.

Analyserne præsenteret i tabel 2 viser oddsene for enten af forlade arbejdsmarkedet før eller efter pensionsalderen grundet ny teknologi som funktion af jobfunktionskategori. I disse analyser indgår arbejde med symboler som reference. Analyserne er justeret for køn og alder, og der vises derfor også oddsene for enten af forlade arbejdsmarkedet før eller 
efter pensionsalderen grundet ny teknologi som funktion af alder (ved stigning på et år) og køn (med mænd som reference).

Analyserne præsenteret i tabel 3 og 4 viser oddsene for enten af forlade arbejdsmarkedet før eller efter pensionsalderen grundet ny teknologi som funktion af de uafhængige variable indenfor hvert stratum. Analyserne er justeret for køn og alder og de uafhængige variabel er medtaget én for én (dvs. ikke gensidigt justeret).

\section{Resultater}

\section{Deskriptivt}

Karakteristik af respondenterne fremgår af tabel 1. Herunder beskrives udvalgte karakteristika. For en mere fyldestgørende gennemgang, henvises til tabel 1 .

Af de 5395 deltagere, der arbejder med symboler, var $47 \%$ kvinder, mens dette var tilfældet for $70 \%$ af de 3528 deltagere, der arbejder med mennesker, og 16\% af de 1853 deltagere, der arbejder med produktion.

Blandt deltagerne, der arbejder med symboler, angav $75 \%$, at der er indført ny teknologi i arbejdet indenfor de seneste 2 år. Dette var tilfældet for $71 \%$ af dem, der arbejder med mennesker og 58\% a dem, der arbejder med produktion.

Blandt dem, der arbejder med symboler, angav $11 \%$ at den nye teknologi kan have betydning for at forlade arbejdsmarkedet før folkepensionsalderen (push), mens det for $78 \%$ ikke havde betydning. Blandt dem, der arbejder med mennesker, angav 14\%, at den nye teknologi kan have betydning for at forlade arbejdsmarkedet før folkepensionsalderen, mens det for $73 \%$ ikke havde betydning. Blandt dem, der arbejder med produktion, angav $8 \%$, at den nye teknologi kan have betydning for at forlade arbejdsmar- kedet før folkepensionsalderen, mens det for 79\% ikke havde betydning.

Blandt dem, der arbejder med symboler, angav $16 \%$, at den nye teknologi kan have betydning for at blive på arbejdsmarkedet til efter folkepensionsalderen (stay), mens det for 59\% ikke havde betydning. Blandt dem, der arbejder med mennesker, angav 10\%, at den nye teknologi kan have betydning for at blive på arbejdsmarkedet til efter folkepensionsalderen, mens det for $68 \%$ ikke havde betydning. Blandt dem, der arbejder med produktion, angav $14 \%$, at den nye teknologi kan have betydning for at blive på arbejdsmarkedet til efter folkepensionsalderen, mens det for 59\% ikke havde betydning.

\section{Ny teknologi og arbejdsmarkeds- tilknytning mellem strata}

Tabel 2 viser sammenhængen mellem jobfunktionskategori og oddsene for at angive at forlade arbejdsmarkedet før eller efter pensionsalderen grundet ny teknologi. Sammenlignet med arbejde med symboler, fandt vi statistisk signifikant højere odds for at forlade arbejdsmarkedet før pensionsalderen grundet ny teknologi (push) blandt dem, der arbejder med mennesker (OR: 1.423; 95\%KI: 1.1951.694). Vi fandt ingen signifikant forskel $i$ at forlade arbejdsmarkedet før pensionsalderen grundet ny teknologi mellem dem, der arbejder med symboler og dem, der arbejder med produktion (OR: 0.940; 95\%KI: 0.717-1.232). I analyserne fandt vi ingen signifikant betydning af hverken køn eller alder.

Sammenlignet med arbejde med symboler, fandt vi statistisk signifikant lavere odds for at blive på arbejdsmarkedet til efter pensionsalderen grundet ny teknologi (stay) blandt dem, der arbejder med mennesker (OR: 0.619; 95\%KI: 0.513-0.746). Vi fandt ingen signifikant forskel i at blive på arbejdsmarkedet til efter pensionsalderen grundet ny teknologi 
mellem dem, der arbejder med symboler og dem, der arbejder med produktion (OR: 0.815; 95\% KI: 0.644-1.031). I analyserne fandt vi yderligere, at kvinder har statistisk signifikant lavere odds for at blive på arbejdsmarkedet til efter pensionsalderen grundet ny teknologi (OR: 0.459; 95\%KI: 0.387-0.544) sammenlignet med mænd. I analyserne fandt vi ingen signifikant betydning af alder.

\section{Ny teknologis betydning for push indenfor stratum}

Tabel 3 viser sammenhængen mellem de uafhængige variable og oddsene for at angive at forlade arbejdsmarkedet før pensionsalderen grundet ny teknologi (push) indenfor for hver jobfunktionskategori. Her ses det, at dem, der arbejder med symboler og mennesker - og angiver at være blevet inddraget i den måde ny teknologi er blevet indført - har signifikant lavere odds for at forlade arbejdsmarkedet før pensionsalderen grundet ny teknologi.

Tabellen viser også, at dem, der har brug for nye kompetencer som følge af den nye teknologi, indenfor hver jobfunktionskategori, har signifikant højere odds for at forlade arbejdsmarkedet før pensionsalderen grundet ny teknologi. Vi fandt også, at dem, der tilbydes tilstrækkelig uddannelse i brug af den nye teknologi, indenfor hver jobfunktionskategori, har signifikant lavere odds for at forlade arbejdsmarkedet før pensionsalderen grundet ny teknologi.

Tabellen viser endvidere, at dem, der angiver at den nye teknologi forringer kvaliteten $i$ arbejdet, indenfor hver jobfunktionskategori, har signifikant højere odds for at forlade arbejdsmarkedet før pensionsalderen grundet ny teknologi. Det ses også, at dem, der angiver at den nye teknologi løfter kvaliteten i arbejdet, indenfor hver jobfunktionskategori, har signifikant lavere odds for at forlade arbejdsmarkedet før pensionsalderen grundet ny teknologi.

\section{Ny teknologis betydning for stay indenfor stratum}

Tabel 4 viser sammenhængen mellem de uafhængige variable og oddsene for at angive at blive på arbejdsmarkedet til efter pensionsalderen grundet ny teknologi (stay) indenfor for hver jobfunktionskategori. Her ses det, at dem, der angiver at være blevet inddraget i den måde ny teknologi er blevet indført, indenfor hver jobfunktionskategori, har signifikant højere odds for at blive på arbejdsmarkedet til efter pensionsalderen grundet ny teknologi.

Tabellen viser også, at dem, der arbejder med symboler og har brug for nye kompetencer som følge af den nye teknologi, har signifikant højere odds for at blive på arbejdsmarkedet til efter pensionsalderen grundet ny teknologi. Vi fandt også, at dem, der arbejder med mennesker og tilbydes tilstrækkelig uddannelse i brug af den nye teknologi, har signifikant højere odds for at blive på arbejdsmarkedet til efter pensionsalderen grundet ny teknologi.

Tabellen viser endvidere, at dem, der arbejder med symboler og angiver at den nye teknologi forringer kvaliteten i arbejdet, har signifikant lavere odds for at blive på arbejdsmarkedet til efter pensionsalderen grundet ny teknologi. Det ses også, at dem, der angiver at den nye teknologi løfter kvaliteten i arbejdet, indenfor hver jobfunktionskategori, har signifikant højere odds for at blive på arbejdsmarkedet til efter pensionsalderen grundet ny teknologi.

\section{Diskussion}

De fuldt justerede analyser viste, højere odds for at forlade arbejdsmarkedet før pensionsalderen grundet ny teknologi (push) og lavere odds for at blive på arbejdsmarkedet til efter pensionsalderen grundet ny teknologi (stay) blandt seniorerne, der arbejder med menne- 
sker. Dertil bidrager ny teknologi i arbejdet i mindre grad til stay blandt kvinder, mens hverken push eller stay grundet ny teknologi ser ud til at være betinget af seniorernes alder. Studiet viste også, at faktorer som inddragelse i indførelsen af den nye teknologi, tilstrækkelig uddannelse i brug af den nye teknologi, at have brug for nye kompetencer som følge af den nye teknologi, samt om den nye teknologi enten løfter eller forringer kvaliteten i arbejdet har betydning for, om teknologien opleves som en push eller stay-faktor.

\section{Ny teknologi som en push- eller stay-faktor}

Størstedelen af seniorerne - på tværs af jobfunktionskategori - havde fået indført ny teknologi i deres arbejde indenfor de seneste to år. Dog angav en større andel af seniorerne, der arbejder med symboler (75\%) og mennesker (71\%) at have fået indført ny teknologi sammenlignet med dem, der arbejder med produktion (58\%). Ud fra frekvenserne præsenteret i tabel 1 ses det, at dem, der arbejder med mennesker, i højere grad angiver ny teknologi som en push-faktor, der forringer kvaliteten i arbejdet, sammenlignet med dem, der arbejder med symboler og produktion. Derimod, angiver dem, der arbejder med symboler, i højere grad ny teknologi som en stay-faktor, der løfter kvaliteten i arbejdet. Det er dog vigtigt at nævne, at for de fleste seniorer på tværs af jobfunktionskategori (59 - 79\%) ser ny teknologi ikke ud til at være en faktor, der alene kan få dem til at blive eller gå. Dette syntes plausibelt, eftersom årsagerne til tilbagetrækning fra arbejdsmarkedet er komplekse og dynamiske, hvor både faktorer knyttet til både individet, arbejdspladsen, familien og det nære sociale netværk, og arbejdsmarkedet og dets politikker har betydning (Poulsen, 2017).

Ovenstående frekvenser, spiller fint sammen med resultaterne fra den logistiske re- gression. Her fandt vi, at dem, der arbejder med mennesker, har højere odds for at forlade arbejdsmarkedet før pensionsalderen grundet ny teknologi og lavere odds for at blive på arbejdsmarkedet til efter pensionsalderen grundet ny teknologi, sammenlignet med de to andre jobfunktionskategorier. Selvom denne sammenhæng var statistisk signifikant, må den dog betegnes som svag på baggrund af størrelsen på OR. Det ser altså ud til, at oplevelsen af ny teknologi som en faktor, der kan have betydning for at blive eller gå, i høj grad er afhængig af hvilken type arbejde, seniorerne udfører. Et tidligere studie har ligeledes fundet, at f.eks. velfærdsteknologier indenfor arbejde i ældreplejen (arbejde med mennesker) kan opleves at være i konflikt med plejepersonalets faglige identitet og værdier (Ajslev et al., 2019). Dette understøttes af et kvalitativt studie i samme branche, der beskriver, at ny teknologi på den ene side kan reducere de fysiske belastninger i arbejdet og bidrage til rehabilitering og selvhjulpenhed, mens den på den anden side kan bidrage til øget tidspres, reduceret menneskelig interaktion og jobusikkerhed (Ajslev et al., 2017). Hvorvidt disse karakteristika kan generaliseres på tværs af seniorerne, der arbejder med mennesker - som dækker over arbejde med mennesker, service, omsorg - kan studiet ikke svare på. Men det kunne tyde på, at teknologiens evne til for nogen at være i konflikt med den faglige identitet kan være særligt knyttet til den menneskelige interaktion der finder sted i arbejdet med mennesker.

Flere undersøgelser har da også vurderet brugen af nye teknologier og de måder, hvorpå disse arbejder sammen med fagidentitet, blandt ansatte i sundhedssektoren. Clark og Thompson viser, hvordan medarbejdere i sundhedssektoren oplevede en reduktion af mening i arbejdet som følge af introduktionen af ny teknologi i journaliserings-systemer og levering af plejeopgaver (Clark \& Thompson, 2015). Det er muligt at eks. 
sundhedsplatformen i Danmark har ført til, at de der arbejder med mennesker, i højere grad oplever den nye teknologi som en push faktor. Andre undersøgelser har endvidere vist, hvordan faglig identitet i sundhedssektoren og ældreplejen er centreret i værdier omkring pleje og omsorg (Mueller et al., 2008; Waerness, 1984). Selv om opfyldelse af disse værdier kan indebære modsætninger og konflikter i interaktioner med den plejekrævende borger (Tronto, 1993; Tronto, 2001), kan denne faglige identitet bidrage til modstand mod nye teknologier, enten fordi de opleves at komme i vejen for de omsorgsfulde aspekter af arbejdet (Clark \& Thompson, 2015), eller fordi de opleves at mindske plejearbejderes autonomi eller faglighed (Berg, 1997; Boonstra et al., 2004).

\section{Push og stay faktorer forbundet med indførelsen af ny teknologi}

For alle jobfunktionskategorier, var inddragelse i indførslen af den nye teknologi svagt til moderat sammenhængende med højere odds for, at teknologien blev oplevet som en stay-faktor. Dertil var inddragelse også forbundet med lavere odds for, at teknologien blev oplevet som en push-faktor blandt seniorerne, der arbejder men symboler og mennesker. Her blev sammenhængene kategoriseret som moderate til stærke. Inddragelse af seniorerne i indførsel af den nye teknologi ser derfor ud til at være et vigtigt parameter, der både hænger sammen med, om den nye teknologi kan have betydning for at forlade arbejdsmarkedet før eller efter folkepensionsalderen. For at den nye teknologi skal kunne bidrage positivt til arbejdet, er det afgørende, at brugeren er involveret i udviklingsprocessen og indførelsen (Cooke, 2002). Da det ofte er arbejdstagerne selv, der har den største viden og erfaring om eget arbejde, kan inddragelse i både planlægning, udvikling, design og afprøvning af den nye teknologi have afgørende betydning for om seniorerne er parate og villige til at arbejde med den nye teknologi (Grothe \& Bruus, 2015). Hvis den nye teknologi indføres på en inddragende måde og opleves som meningsfuld, kan den sandsynligvis lettere finde plads i den faglige identitet på tværs af jobfunktioner og bidrage til at løfte kvaliteten i arbejdet (Ajslev et al., 2017).

Omkring halvdelen af seniorerne på tværs af jobfunktion nævnte, at de havde brug for nye kompetencer som følge af den nye teknologi. Analyserne viste en moderat positiv sammenhæng mellem dette behov og intentionen om at forlade arbejdsmarkedet før pensionsalderen grundet ny teknologi blandt de seniorer, der arbejder med symboler og mennesker, og en svag sammenhæng blandt dem, der arbejder med produktion. Endvidere fandt vi, at behov for nye kompetencer også havde betydning for stay blandt seniorerne, der arbejder med symboler. Bedømt ud fra størrelsen på OR og 95\%KI ser "behov for nye kompetencer" dog ud til at være en stærkere push end stay faktor. Det ser derfor ud til, at mangel på kompetencer kan skubbe én ud af arbejdsmarkedet før tid, men de nødvendige kompetencer i sig selv gør kun i mindre grad, at dem, der arbejder med symboler, er motiveret til at arbejde efter folkepensionsalderen.

At tilbydes tilstrækkelig uddannelse i brugen af den nye teknologi - især hvis den nye teknologi kræver nye og opdaterede færdigheder - ser ud til at have betydning for både at gå før eller blive til efter folkepensionsalderen. Specifikt fandt vi moderat sammenhæng mellem tilstrækkelig uddannelse i brug af den nye teknologi og lavere odds for push for alle jobfunktionskategorier, og højere odds for stay blandt seniorerne, der arbejder med mennesker og symboler. Uddannelse og opkvalificering - ikke nødvendigvis knyttet til nye teknologier - er tidligere blevet kædet sammen med sandsynligheden for at blive 
på arbejdsmarkedet (Lawless et al., 2015; Laaksonen et al., 2018; Møberg, 2011), og kan være et afgørende instrument til at øge seniorernes ressourcer, så de bliver i stand til at håndtere og betjene den nye teknologi i arbejdet. En tidligere litteraturgennemgang af faktorer, som påvirker ældre sygeplejersker (arbejde med mennesker) til at forlade en organisation eller gå tidligt på pension, identificerede karriereudvikling og uddannelse som nøglefaktorer, der kan påvirke denne beslutning (Moseley et al., 2008). Forfatterne argumenterede, at efteruddannelse og kompetenceudvikling kan være specielt vigtig for ældre sygeplejersker (+50 år), da de har indset at tempoet i de teknologiske forandringer påvirker deres evne til at klare deres arbejde (Andrews et al., 2005). I den forbindelse er det ligeledes vigtigt at fremhæve de rå frekvenser præsenteret i tabel 1, der viser, at dem, der arbejder med symboler (68\%) i højere grad tilbydes tilstrækkelig uddannelse i den nye teknologi sammenlignet med dem, der arbejder med mennesker (54\%) og produktion (54\%). Givet betydningen af uddannelse for oplevelsen af ny teknologi som enten en push- eller stay-faktor, syntes det især vigtigt at virksomheder, hvis kerneopgave er arbejde med mennesker eller produktion, har fokus på at designe og tilbyde relevant undervisning i brugen af den nye teknologi.

Både inddragelse i indførsel og uddannelse i brug af den nye teknologi kan være afgørende faktorer for om den nye teknologi kan løfte eller forringe kvaliteten i arbejdet. Det kan dog ud fra vores datamateriale, være vanskeligt at afgøre afgrænsningen imellem de to faktorer - indflydelse og uddannelse. Nyere forskning i seniorers arbejdsmarkedstilknytning peger således på, at stereotypificering af ældre medarbejdere har betydning for ønsket om tilbagetrækning. Her viser det sig, at negativ stereotypificering, $\mathrm{fx}$ forventninger fra ledelsens side om, at ældre medarbejdere vil yde modstand imod forandringer, nye teknologier, kompetenceudvikling og ny viden, har vist sammenhæng med tidligere tilbagetrækning (Andersen \& Jensen, 2011; Thorsen et al., 2016). Hvorvidt det således er den konkrete uddannelse i nye teknologier, der er vigtig for seniorers ønske om at blive på arbejdspladsen, kan således være svært at sige, da selve tilbuddet om uddannelse kan rumme en positiv tilkendegivelse fra virksomhedens eller ledelsens side, om at man gerne vil investere $\mathrm{i}$, inddrage og fastholde den ældre medarbejder. Anden forskning har peget på, at det særligt er ældre medarbejdere, som er højt placeret i stillingshierarkier, der tilbydes videreuddannelse, og som oplever at virksomhederne gør noget for at fastholde dem (Jakobsen et al., 2014) . Dette kan give noget af forklaringen på, hvorfor folk, der arbejder med symboler, oftere oplever at blive tilbudt tilstrækkelig uddannelse, men afhjælper jo ikke den udfordring, at tilbud om uddannelse - herunder i relation til nye teknologier - som en mere udbredt mulighed vil kunne være en yderligere stay-faktor. Der findes dog et utal af andre faktorer som yderligere kan relatere sig til dette så som seniorernes helbred, jobusikkerhed som følge af den nye teknologi, at teknologien føles meningsfuld i arbejdskonteksten, at den spiller sammen med fagidentiteten, at den fører til tidspres mm. Hvad, vi kan se ud fra studiets resultater, er, at når seniorerne - på tværs af jobfunktion - oplever, at den nye teknologi løfter kvaliteten i arbejdet, så er oddsene for, at den nye teknologi opleves som en push-faktor, lavere. I modsætning, så er oddsene for push højere, når seniorerne oplever at den nye teknologi forringer kvaliteten i arbejdet. I tillæg til dette, er det vigtigt at fremhæve, at ca. dobbelt så mange seniorer, der arbejder med mennesker (23\%), angav at den nye teknologi forringer kvaliteten i arbejdet sammenlignet med dem, der arbejder med symboler (10\%) og produktion $(12 \%)$. Dette understøtter de tidligere analyser, der 
viser, at indførslen af ny teknologi kan have størst konsekvenser for arbejdslivslængden for denne gruppe af arbejdstagere. Det er dog vigtigt at nævne, at der inden for alle tre jobfunktionskategorier er flere, der mener, at kvaliteten i arbejdet løftes af den nye teknologi end at den nye teknologi forringer kvalteten i arbejdet (Tabel 1). Så selvom næsten dobbelt så mange seniorer, der arbejder med mennesker, angav, at den nye teknologi forringer kvaliteten $\mathrm{i}$ arbejdet sammenlignet med de andre to kategorier, så er der i denne gruppe stadig næsten dobbelt så mange (41\% $\bmod 23 \%$ ), som har et positivt frem for et negativt syn på teknologiens betydning for kvaliteten i deres arbejde.

Oplevelsen af kvalitet i arbejdet kan også have betydning for at blive i arbejdet til efter folkepensionsalderen. For alle jobfunktionskategorier var der højere odds for at den nye teknologi blev oplevet som en stay-faktor, hvis den løftede kvaliteten i arbejdet (stærk sammenhæng). Blandt de seniorer der arbejder med symboler og oplevede at den nye teknologi forringede kvaliteten i arbejdet, var der signifikant lavere odds for at teknologien blev oplevet som en stay-faktor. For de resterende jobkategorier var denne sammenhæng ikke statistisk signifikant. Estimaterne var dog under 1 og konfidensintervallerne brede, hvilket kunne tyde på, at der ikke i vores datasæt var tilstrækkelig statistisk power til at kunne illustrere denne sammenhæng. Dette spiller fint sammen med, at der var færre seniorer der arbejder med mennesker og produktion sammenlignet med dem, der arbejder med symboler, i tillæg til at en forholdsvis lav procentdel angav at den nye teknologi forringer kvaliteten $\mathrm{i}$ arbejdet.

\section{Styrker og svagheder}

Studiet har både styrker og begrænsninger. En styrke er Danmarks Statistiks procedure for udtrækning af stikprøven, der sikrer 1) at alle i populationen (lønnede arbejdstagere over 50 år) skal kunne udvælges, 2) at udvælgelsen sker med lodtrækning, samt 3) at sandsynligheden for at blive valgt med lodtrækning er kendt. Som i alle spørgeskemaundersøgelser kan manglende besvarelser være en begrænsning for undersøgelsens repræsentativitet. For at tage højde for dette, blev der foretaget en vægtning af data, hvilket betyder, at hver respondent tildeles en vægt i forhold til antallet af personer i det givne stratum (branchegruppe). Vægtene blev korrigeret ved hjælp af Danmarks Statistiks registeroplysninger. Samlet sikrede ovenstående procedurer, at data er repræsentativt for arbejdstagere over 50 år i Danmark hvilket styrker generaliserbarheden af studiets resultater (L.L. Andersen et al., 2019; Andersen $\&$ Sundstrup, 2019). Endvidere er det vigtigt at nævne, at mellem 8 og 16\% af seniorerne, på tværs af jobfunktionskategori, oplever, at ny teknologi har betydning for at gå før eller efter pensionsalderen. Dette repræsenterer netop den afhængige variabel i nærværende statistiske analyse, og kan derfor potentielt have medvirket til at nogle af de sammenhænge der illustreres i tabel 2 enten er svage eller ikke signifikante.

Det er ligeledes vigtigt at nævne, at en vis andel af seniorerne besvarede "ved ikke" til spørgsmålene, om hvorvidt den nye teknologi kan have betydning for at forlade arbejdsmarkedet før (11-13\%) eller efter folkepensionsalderen (21-27\%). Disse besvarelser blev frasorteret i den logistiske regressionsanalyse, og indgik dermed ikke i bestemmelsen af odds ratio for enten af forlade arbejdsmarkedet før eller efter pensionsalderen grundet ny teknologi. Generaliserbarheden af studiets resultater vedrører derfor ikke de seniorer, der er i tvivl om, hvorvidt den nye teknologi har betydning for deres arbejdslivslængde.

En svaghed ved nærværende studie er, at opdeling af seniorernes jobfunktion (dvs. arbejde med symboler, mennesker eller produk- 
tion) blev bestemt på baggrund af et spørgsmål om, hvad seniorerne først og fremmest arbejder med. En opdeling på baggrund af registerbaserede branchekoder vil kunne have medvirket til an mere nuanceret inddeling og elimineret eventuel bias forbundet med bestemmelse af jobfunktion på baggrund af en spørgeskemabesvarelse.

Det er vigtigt at nævne, at vi ser på sammenhængen mellem ny teknologi og seniorernes forventede tilbagetrækningssalder og ikke den faktiske pensionsalder. Dertil er studiet en tværsnitsundersøgelse, der af natur ikke kan belyse årsagssammenhænge mellem ny teknologi i arbejdet og intentionen om at blive eller gå. En fremtidig register-opfølgning på data er derfor nødvendig for at se, om ny teknologi og faktorer knytter til indførsel og uddannelse af denne kan være med til forlænge eller forkorte arbejdslivet. Baseret på nærværende resultater kan en hypotese dog være, at måden hvorpå ny teknologi indføres (herunder om seniorerne inddrages og om de tilbydes tilstrækkelig uddannelse i dets brug) kan være forbundet med den faktiske pensionsalder i de kommende år.

Endvidere kan studiet ikke belyse, hvad der bl.a. ligger til grund for, at den nye teknologi enten kan løfte eller forringe kvaliteten i arbejdet, eller hvordan man bedst muligt får teknologien til at spille sammen med fagidentiteten. Det har heller ikke været muligt

\section{REFERENCER}

Ajslev, Z. N. A., Johansen, H. H. \& Poulsen, O. M. (2017). Nye teknologier i aeldreplejen - Plejecentres implementering af velfoerdsteknologier og teknologiernes betydninger for arbejdsmiljø og fagidentitet. Det Nationale Forskningscenter for Arbejdsmiljø (NFA).

Ajslev, Z. N. A., Sundstrup, E., Johansen, H. H., Sørensen, K., Jensen, K. A. \& Poulsen, O. M. (2019). Arbejdsmiljømoessige udfordringer som følge af automatisering og digitalisering - En baseret på nærværende undersøgelse at gå i detaljer med typen af ny teknologi inden for hver jobfunktionskategori. Fremtidige kvalitative studier kan derimod belyse dette og sammenstille resultaterne med nærværende studie for herigennem at udarbejde retningslinjer for god indførsel af ny teknologi på arbejdspladsen, der både tager højde for arbejdstager og arbejdsgivers ønsker og forventninger til den nye teknologi.

\section{Konklusion}

Indførsel af ny teknologi i arbejdslivet ser ud til at være en faktor, der har betydning for seniorernes beslutning om at forlade arbejdsmarkedet før eller efter folkepensionsalderen. Især syntes indførslen af ny teknologi at have betydning for seniorerne, der arbejder med mennesker, som i højere grad er udsatte for et blive skubbet ud af arbejdsmarkedet grundet den nye teknologi og som i højere grad oplever, at deres arbejde forringes af den nye teknologi. Dertil viste studiet, at faktorer som inddragelse i indførelsen af den nye teknologi, tilstrækkelig uddannelse i brug af den nye teknologi, at have brug for nye kompetencer som følge af den nye teknologi, samt om den nye teknologi enten løfter eller forringer kvaliteten i arbejdet har betydning for, om teknologien opleves som en push- og/ eller stay-faktor.

rapport om trends og tendenser med relevans for fremtidens arbejdsmarked. Det Nationale Forskningscenter for Arbejdsmiljø.

Andersen, J. \& Jensen, P. (2011). Tilbagetraekning fra arbejdsmarkedet - årsager og effekter. Frydenlund.

Andersen, Lars Louis, Fallentin, N., Thorsen, S. V. \& Holtermann, A. (2016). Physical workload and risk of long-term sickness absence in the general working population and among 
blue-collar workers: prospective cohort study with register follow-up. Occupational and Environmental Medicine, 73(4), 246-253. https:// doi.org/10.1136/oemed-2015-103314

Andersen, L. L., Jensen, P. H. \& Sundstrup, E. (2019). Barriers and opportunities for prolonging working life across different occupational groups: the SeniorWorkingLife study. European Journal of Public Health. https://doi. org/10.1093/eurpub/ckz146

Andersen, L.L. \& Sundstrup, E. (2019). Study protocol for SeniorWorkingLife - push and stay mechanisms for labour market participation among older workers. BMC Public Health, 19(1), 133. https://doi.org/10.1186/s12889019-6461-6

Andrews, J., Manthorpe, J. \& Watson, R. (2005). Employment transitions for older nurses: a qualitative study. Journal of Advanced Nursing, 51(3), 298-306. https://doi.org/10.1111/j.13652648.2005.03501.x

Arntz, M., Gregory, T. \& Zierahn, U. (2016). The Risk of Automation for Jobs in OECD Countries (OECD Social, Employment and Migration Working Papers Nr. 189). https://doi. org/10.1787/5jlz9h56dvq7-en

Arvidsson, I., Balogh, I., Hansson, G.-Å., Ohlsson, K., Akesson, I. \& Nordander, C. (2012). Rationalization in meat cutting - consequences on physical workload. Applied ergonomics, 43(6), 1026-1032. https://doi.org/10.1016/j. apergo.2012.03.001

Bach, E., Andersen, L. L. \& Bjørner, J. B. (2018). Arbejdsmiljø og helbred i Danmark. http:// www.arbejdsmiljoforskning.dk/da/nyheder/ arkiv/2011/samlet-rapport-om-arbejdsmiljoe-og-helbred-i-danmark-2010

Bach, E. \& Johnsen, N. F. (2016). Arbejdsmiljø \& Helbred i Danmark 2016. https://arbejdsmiljodata.nfa.dk/

Berg, M. (1997). Rationalizing Medical Work: Decision Support Techniques and Medical Practices. The MIT Press.

Boonstra, A., Boddy, D. \& Fischbacher, M. (2004). The limited acceptance of an electronic prescription system by general practitioners: reasons and practical implications. New Technology, Work and Employment, 19(2), 128-144. https://doi.org/10.1111/j.02681072.2004.00132.x
Chen, H., Cohen, P. \& Chen, S. (2010). How Big is a Big Odds Ratio? Interpreting the Magnitudes of Odds Ratios in Epidemiological Studies. Communications in Statistics - Simulation and Computation, 39(4), 860-864. https://doi. org/10.1080/03610911003650383

Clark, I. \& Thompson, A. (2015). Healthcare Assistants: distributional losses as a consequence of NHS modernisation?: Healthcare Assistants. New Technology, Work and Employment, 30(3), 209-221. https://doi.org/10.1111/ntwe.12053

Cooke, F. L. (2002). The Important Role of the Maintenance Workforce in Technological Change: A Much Neglected Aspect. Human Relations, 55(8), 963-988. https://doi. org/10.1177/0018726702055008179

Damm, E. A. (2017). Teknologiske forandringer på arbejdsmarkedet. Arbejderbevægelsens Erhvervsråd.

Grothe, H. \& Bruus, P. (2015). Den Teknologiske Stepmodel. Teknologisk Institut DMRI; Version 2.0.

Hinrichsen, L. (2010). Manufacturing technology in the Danish pig slaughter industry. Meat Science, 84(2), 271-275. https://doi. org/10.1016/j.meatsci.2009.03.012

Jakobsen, V., Jensen, S., Holt, H., \& Larsen, M. (2014). Virksomheders sociale engagement. SFI - det nationale forskningscenter for velfærd.

Lawless, M., Buggy, C. J. \& Codd, M. B. (2015). Educational influences on early retirement through disability in Ireland. Occupational Medicine, 65(4), 303-308. https://doi.org/10.1093/ occmed/kqv005

Laaksonen, M., Rantala, J., Järnefelt, N. \& Kannisto, J. (2018). Educational differences in years of working life lost due to disability retirement. European Journal of Public Health, 28(2), 264-268. https://doi.org/10.1093/eur$\mathrm{pub} / \mathrm{ckx} 221$

McGregor, J. \& Gray, L. (2002). Stereotypes and older workers: The New Zealand experience. Issue 18.

Meng, A., Jensen, P. H., Albertsen, K., Sundstrup, E. \& Andersen, L. L. (2019). Stereotypier, fordomme og aldersdiskrimination. I Kapitel 12. Afrapportering af projektet SeniorArbejdsLiv.

Moseley, A., Jeffers, L. \& Paterson, J. (2008). The retention of the older nursing workforce: A literature review exploring factors that influence the retention and turnover of older nurses. 
Contemporary Nurse, 30(1), 46-56. https://doi. org/10.5172/conu.673.30.1.46

Mueller, F., Valsecchi, R., Smith, C., Gabe, J. \& Elston, M. A. (2008). 'We are nurses, we are supposed to care for people': professional values among nurses in NHS Direct call centres. New Technology, Work and Employment, 23(1-2), 2-16. https://doi.org/10.1111/j.1468005X.2008.00199.x

Møberg, R. J. (2011). Kapitel 7 Betydning af efteruddannelse for fastholdelse af ældre på arbejdsmarkedet. I Tilbagetraekning fra arbejdsmarkedet - årsager og effekter (Jørgen Goul Andersen \& Per H. Jensen): Bd. 1. udgave, 1 oplag (s. 129-135). Bogforlaget Frydenlund.

Poulsen, O. M. (2017). Notat vedr. sammenstilling af dansk viden om arbejdsmiljøets betydning for fastholdelse af aeldre arbejdstagere. NFA.

Stacey, N., Ellwood, P., Bradbrook, S., Reynolds, J. \& Williams, H. (2017). Key trends and drivers of change in information and communication technologies and work location. Foresight on new and emerging risks in OSH. Working report. European Agency for Safety and Health at Work. Sundstrup, E., Hansen, Å. M., Mortensen, E. L., Poulsen, O. M., Clausen, T., Rugulies, R., Møl- ler, A. \& Andersen, L. L. (2017). Cumulative occupational mechanical exposures during working life and risk of sickness absence and disability pension: prospective cohort study. Scandinavian Journal of Work, Environment \& Health, 43(5), 415-425. https://doi.org/10.5271/ sjweh.3663

Thorsen, S. V., Jensen, P. H. \& Bjørner, J. B. (2016). Psychosocial work environment and retirement age: a prospective study of 1876 senior employees | SpringerLink. International Archives of Occupational and Environmental Health, 89, 891-900.

Tronto, J. (1993). Moral Boundaries: A Political Argument for an Ethic of Care. Routledge.

Tronto, J. (2001). An Ethic of Care. I Voices of Community Care: Ethics, Aging and Caring Practices, by Hirschmann, NJ and Di Stefano, C (Eds.) (s. 139-156). Westview Press.

Tænketanken - Den nye 3. alder. (2018). Anbefalinger til Det gode liv $i$ den tredje alder frem mod 2040. Institut for Fremtidsforskning i regi af Tænketanken - Den nye 3. alder.

Waerness, K. (1984). The Rationality of Caring. Economic and Industrial Democracy, 5(2), 185-211. https://doi.org/10.1177/0143831X8452003

\section{TABELLER}

Tabel 1. Karakteristik af respondenterne.

\begin{tabular}{llll} 
& Symboler & Mennesker & Produktion \\
Antal (n) & 5395 & 3528 & 1853 \\
\hline Alder (mean, SE) & $56,3(0,075)$ & $56,9(0,084)$ & $56,3(0,125)$ \\
\hline Køn (andel kvinder i \%) & 47 & 70 & 16 \\
\hline $\begin{array}{l}\text { Er der indført ny teknologi i dit arbejde } \\
\text { indenfor de seneste 2 år? }\end{array}$ & 75 & 71 & \\
Ja & 25 & 29 & 58 \\
Nej & & & 43 \\
\hline
\end{tabular}


Jeg er blevet inddraget i den måde den nye teknologi er blevet indført Ja

Nej

Ved ikke

$31 \quad 34$

35

3

4

4

Jeg har behov for nye kompetencer som følge af den nye teknologi

$\begin{array}{llll}\text { Ja } & 54 & 55 & 48 \\ \text { Nej } & 40 & 39 & 44 \\ \text { Ved ikke } & 6 & 7 & 9\end{array}$

Jeg tilbydes tilstrækkelig uddannelse i brug af den nye teknologi

$\begin{array}{llll}\text { Ja } & 68 & 54 & 54 \\ \text { Nej } & 23 & 35 & 33 \\ \text { Ved ikke } & 9 & 10 & 13\end{array}$

\begin{tabular}{llll}
\hline $\begin{array}{l}\text { Den nye teknologi forringer kvaliteten } \\
\text { i mit arbejde }\end{array}$ & & \\
Ja & 10 & 23 & 12 \\
Nej & 80 & 62 & 78 \\
Ved ikke & 9 & 15 & \\
\hline Den nye teknologi løfter kvaliteten & & & \\
i mit arbejde & 56 & 51 \\
Ja & 24 & 32 \\
Nej & 19 & 41 & \\
Ved ikke & 35 & \\
\hline Den nye teknologi kan have betydning & & 24 & 79 \\
for at jeg forlader arbejdsmarkedet & & & \\
før min folkepensionsalder (PUSH) & 11 & 14 & \\
Ja & 78 & 73 & \\
Nej & 11 & 13 & 14 \\
Ved ikke & & & \\
\hline Den nye teknologi kan have betydning & & & 27 \\
for at jeg bliver på arbejdsmarkedet & & 10 & \\
til efter min folkepensionsalder (STAY) & 16 & 68 & \\
Ja & 59 & 21 & \\
Nej & 25 & & \\
Ved ikke & & & \\
\hline
\end{tabular}


Tabel 2. Sammenhoeng mellem jobfunktionskategori og oddsene for at angive at forlade arbejdsmarkedet før eller efter pensionsalderen grundet ny teknologi. OR = odds-ratio, 95\%KI = 95\% konfidensintervaller. Estimater markeret med fed angiver statistisk signifikans $(p<0.05)$.

\section{Den nye teknologi kan have betydning for at jeg forlader arbejdsmarkedet \\ før min folkepensionsalder (PUSH)}

\begin{tabular}{|c|c|c|}
\hline & OR & $95 \% \mathrm{KI}$ \\
\hline Arbejde med symboler & 1 & \\
\hline Arbejde med produktion & 0.940 & $0.717-1.232$ \\
\hline Arbejde med mennesker & 1.423 & 1.195-1.694 \\
\hline Mand & 1 & \\
\hline Kvinde & 0.952 & $0.803-1.129$ \\
\hline Alder (ved stigning i alder på 1 år) & 0.996 & $0.980-1.012$ \\
\hline \multicolumn{3}{|c|}{$\begin{array}{c}\text { Den nye teknologi kan have betydning for at jeg bliver på arbejdsmarkedet } \\
\text { til efter min folkepensionsalder (STAY) }\end{array}$} \\
\hline & OR & $95 \% \mathrm{KI}$ \\
\hline Arbejde med symboler & 1 & \\
\hline Arbejde med produktion & 0.815 & $0.644-1.031$ \\
\hline Arbejde med mennesker & 0.619 & $0.513-0.746$ \\
\hline Mand & 1 & \\
\hline Kvinde & 0.459 & $0.387-0.544$ \\
\hline Alder (ved stigning i alder på 1 år) & 0.994 & 0.977-1.012 \\
\hline
\end{tabular}


Tabel 3. Sammenhoeng mellem de uafhoengige variable og oddsene for at angive at forlade arbejdsmarkedet før pensionsalderen grundet ny teknologi (PUSH) indenfor for hver jobfunktionskategori (arbejde med symboler, arbejde med produktion, arbejde med mennesker). OR = odds-ratio, 95\%KI = 95\% konfidensintervaller. Estimater markeret med fed angiver statistisk signifikans $(p<0.05)$.

\begin{tabular}{|c|c|c|c|c|c|c|c|c|}
\hline \multicolumn{9}{|c|}{ Betydning for PUSH } \\
\hline \multicolumn{3}{|c|}{ Symboler } & \multicolumn{3}{|c|}{ Produktion } & \multicolumn{3}{|c|}{ Mennesker } \\
\hline $\mathbf{n}$ & OR & 95\% KI & $\mathrm{n}$ & OR & $95 \% \mathrm{KI}$ & $\mathrm{n}$ & OR & $95 \% \mathrm{KI}$ \\
\hline
\end{tabular}

Jeg er blevet inddraget $\mathrm{i}$ den måde den nye teknologi er blevet indført

\begin{tabular}{llcllccccc} 
Nej & 1263 & 1 & & 584 & 1 & & 878 & 1 & \\
$\mathrm{Ja}$ & 2455 & $\mathbf{0 . 3 4 8}$ & $\mathbf{0 . 2 7 3 - 0 . 4 4 4}$ & 320 & 0.702 & $0.410-1.202$ & 1.414 & $\mathbf{0 . 4 2 5}$ & $\mathbf{0 . 3 2 6 - 0 . 5 5 4}$ \\
\hline
\end{tabular}

Jeg har behov for nye kompetencer som følge af den nye teknologi

\begin{tabular}{lccccccccc} 
Nej & 1497 & 1 & & 443 & 1 & & 820 & 1 & \\
$\mathrm{Ja}$ & 2123 & 3.740 & $2.761-5.065$ & 416 & 2.104 & $\mathbf{1 . 2 1 4 - 3 . 6 4 5}$ & 1.417 & $\mathbf{3 . 8 2 5}$ & $\mathbf{2 . 6 9 1 - 5 . 4 3 8}$ \\
\hline
\end{tabular}

Jeg tilbydes

tilstrækkelig

uddannelse

$i$ brug af den nye teknologi Nej $884 \quad 1$ $\begin{array}{lllll}2593 & 0.240 & 0.187-0.310 & 492 & 0.371\end{array}$ $\begin{array}{cccc} & 874 & 1 & \\ \mathbf{0 . 2 1 2 - 0 . 6 4 8} & 1.263 & 0.279 & \mathbf{0 . 2 1 0 - 0 . 3 6 9}\end{array}$

Ja

$\begin{array}{lllllllllll}2593 & 0.240 & 0.187-0.310 & 492 & 0.371\end{array}$

Den nye teknologi forringer kvaliteten i mit arbejde

\begin{tabular}{lccccccccc} 
Nej & 3090 & 1 & & 744 & 1 & & 1443 & 1 & \\
$\mathrm{Ja}$ & 382 & 10.765 & $\mathbf{7 . 9 8 2 - 1 4 . 5 1 7}$ & 102 & $\mathbf{1 0 . 6 0 2}$ & $\mathbf{5 . 6 8 1 - 1 9 . 7 8 3}$ & 575 & $\mathbf{8 . 7 8 8}$ & $\mathbf{6 . 3 9 7 - 1 2 . 0 7 3}$ \\
\hline
\end{tabular}

Den nye

teknologi

løfter

kvaliteten i mit arbejde

\begin{tabular}{lccccccccc} 
Nej & 930 & 1 & & 286 & 1 & & 881 & 1 & \\
$\mathrm{Ja}$ & 2159 & 0.243 & $\mathbf{0 . 1 8 4 - 0 . 3 2 1}$ & 496 & 0.344 & $\mathbf{0 . 1 9 3 - 0 . 6 1 3}$ & 928 & $\mathbf{0 . 3 1 4}$ & $\mathbf{0 . 2 2 8 - 0 . 4 3 2}$ \\
\hline
\end{tabular}


Tabel 4. Sammenhoeng mellem de uafhoengige variable og oddsene for angive at blive på arbejdsmarkedet til efter pensionsalderen grundet ny teknologi (STAY) indenfor for hver jobfunktionskategori (arbejde med symboler, arbejde med produktion, arbejde med mennesker). OR $=$ odds-ratio, 95\%KI = 95\% konfidensintervaller. Estimater markeret med fed angiver statistisk signifikans $(p<0.05)$.

\begin{tabular}{|c|c|c|c|c|c|c|c|c|}
\hline \multicolumn{9}{|c|}{ Betydning for STAY } \\
\hline \multicolumn{3}{|c|}{ Symboler } & \multicolumn{3}{|c|}{ Produktion } & \multicolumn{3}{|c|}{ Mennesker } \\
\hline $\mathrm{n}$ & OR & $95 \% \mathrm{KI}$ & $\mathbf{n}$ & OR & $95 \% \mathrm{KI}$ & $\mathbf{n}$ & OR & $95 \% \mathrm{KI}$ \\
\hline
\end{tabular}

Jeg er blevet inddraget $\mathbf{i}$ den måde den nye teknologi er blevet indført

$\begin{array}{lllllccccc}\text { Nej } & 1263 & 1 & & 584 & 1 & & 878 & 1 \\ \text { Ja } & 2455 & \mathbf{2 . 1 3 3} & \mathbf{1 . 6 5 0 - 2 . 7 5 7} & 320 & \mathbf{2 . 4 8 0} & \mathbf{1 . 4 6 1 - 4 . 2 1 2} & 1.414 & \mathbf{2 . 2 0 7} & \mathbf{1 . 5 0 6 - 3 . 2 3 5}\end{array}$

Jeg har behov for nye kompetencer som følge af den nye teknologi Nej $\begin{array}{llllll}1497 & 1 & 443 & 1 & 820 & 1\end{array}$ $\begin{array}{llllllllll}\mathrm{Ja} & 2123 & 1.521 & 1.201-1.928 & 416 & 1.245 & 0.782-1.981 & 1.417 & 1.159 & 0.811-1.658\end{array}$

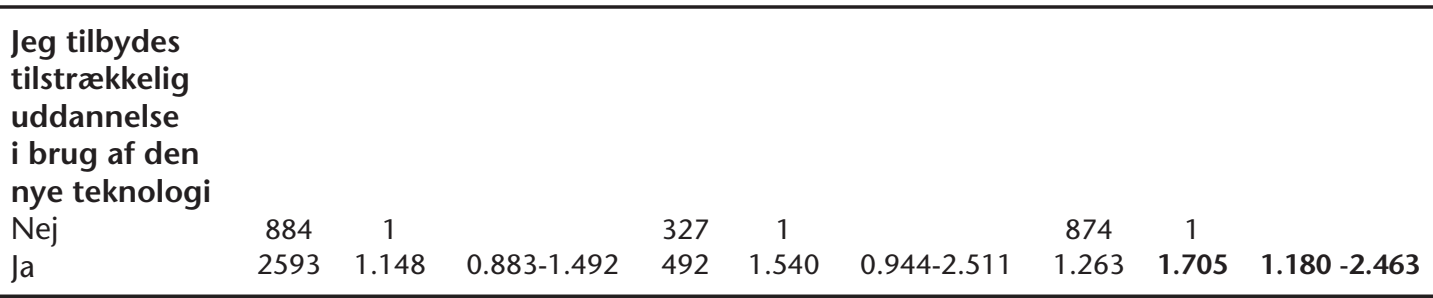

Den nye teknologi forringer kvaliteten i mit arbejde Nej Ja $\begin{array}{lllllll}3090 & 1 & 744 & 1 & 1443 & 1\end{array}$ $\begin{array}{lllllllll}382 & \mathbf{0 . 5 7 2} & \mathbf{0 . 3 8 9 - 0 . 8 4 3} & 102 & 0.488 & 0.210-1.132 & 575 & 0.874 & 0.592-1.290\end{array}$

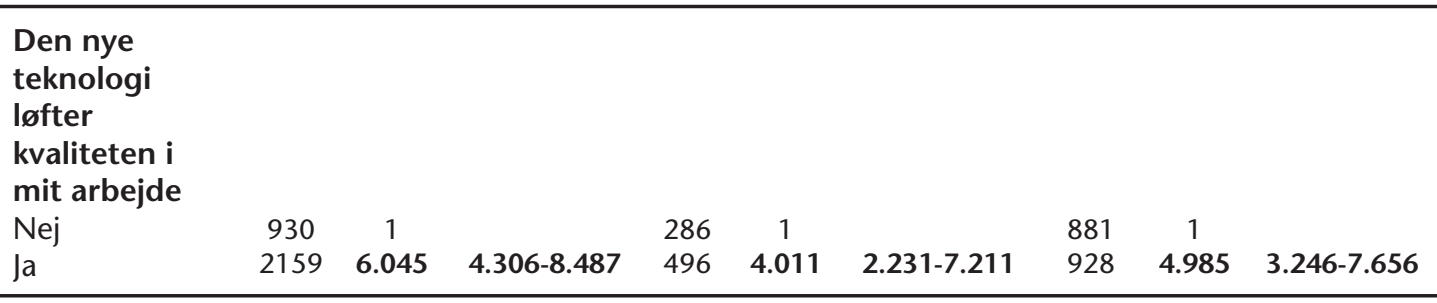


Emil Sundstrup, seniorforsker, ph.d.

Det Nationale Forskningscenter for Arbejdsmiljø

e-mail: esu@nfa.dk

Jeppe Ajslev, seniorforsker, ph.d.

Det Nationale Forskningscenter for Arbejdsmiljø

e-mail: jza@nfa.dk

Lars Louis Andersen, professor, ph.d.

Det Nationale Forskningscenter for Arbejdsmiljø

Institut for Medicin og Sundhedsteknologi, Aalborg Universitet

e-mail:1la@nfa.dk 